\title{
Combination of Electrochemical Processes with Membrane Bioreactors for Wastewater Treatment and Fouling Control: A Review
}

\section{OPEN ACCESS}

Edited by:

Vasudevan Subramanyan, Council of Scientific and Industrial Research-Central Electrochemical

Research Institute, India

Reviewed by: Devendra P. Saroj,

University of Surrey, UK Himabindu Vurimindi, Jawaharlal Nehru Technological

University, India

Gomathi Priya Ponnaiah,

Anna University, India

Doraiswamy Raju Mohan,

Anna University, India

Motakatla Venkateswer Reddy,

Muroran Institute of Technology,

Japan

Lucinda Elizabeth Doyle,

Singapore Centre for Environmental Life Sciences Engineering, Singapore

*Correspondence: Vincenzo Belgiorno v.belgiorno@unisa.it

Specialty section

This article was submitted to

Wastewater Management,

a section of the journal

Frontiers in Environmental Science

Received: 20 May 2016 Accepted: 18 August 2016

Published: 31 August 2016

Citation:

Ensano BMB, Borea L, Naddeo V

Belgiorno V, de Luna MDG and Ballesteros FC Jr (2016) Combination of Electrochemical Processes with

Membrane Bioreactors for

Wastewater Treatment and Fouling

Control: A Review.

Front. Environ. Sci. 4:57.

doi: 10.3389/fenvs.2016.00057

\author{
Benny M. B. Ensano ${ }^{1}$, Laura Borea ${ }^{2}$, Vincenzo Naddeo ${ }^{2}$, Vincenzo Belgiorno ${ }^{2 *}$, \\ Mark D. G. de Luna ${ }^{1,3}$ and Florencio C. Ballesteros Jr.,
}

${ }^{1}$ Environmental Engineering Program, National Graduate School of Engineering, University of the Philippines, Quezon City, Philippines, ${ }^{2}$ Sanitary Environmental Engineering Division, Department of Civil Engineering, University of Salerno, Fisciano, Italy, ${ }^{3}$ Department of Chemical Engineering, University of the Philippines, Quezon City, Philippines

This paper provides a critical review about the integration of electrochemical processes into membrane bioreactors (MBR) in order to understand the influence of these processes on wastewater treatment performance and membrane fouling control. The integration can be realized either in an internal or an external configuration. Electrically enhanced membrane bioreactors or electro membrane bioreactors (eMBRs) combine biodegradation, electrochemical and membrane filtration processes into one system providing higher effluent quality as compared to conventional MBRs and activated sludge plants. Furthermore, electrochemical processes, such as electrocoagulation, electrophoresis, and electroosmosis, help to mitigate deposition of foulants into the membrane and enhance sludge dewaterability by controlling the morphological properties and mobility of the colloidal particles and bulk liquid. Intermittent application of minute electric field has proven to reduce energy consumption and operational cost as well as minimize the negative effect of direct current field on microbial activity which are some of the main concerns in eMBR technology. The present review discusses important design considerations of eMBR, its advantages as well as its applications to different types of wastewater. It also presents several challenges that need to be addressed for future development of this hybrid technology which include treatment of high strength industrial wastewater and removal of emerging contaminants, optimization study, cost benefit analysis and the possible combination with microbial electrolysis cell for biohydrogen production.

Keywords: electro membrane bioreactors (eMBRs), fouling precursors, bacterial activity, electrocoagulation, electroosmosis, electrophoresis, extracellular polymeric substances (EPS), soluble microbial products (SMP)

\section{INTRODUCTION}

Numerous water and wastewater treatment processes have been employed in order to minimize water pollution and to augment drinking water resources (de Luna et al., 2009; Naddeo et al., 2011; Cesaro et al., 2013; Secondes et al., 2014; Ballesteros et al., 2016). Among these techniques, conventional activated sludge (CAS) process is the most widely used method due to 
its effective mineralization of organic and inorganic compounds from various types of wastewater. However, CAS has been shown to have limited capability of degrading recalcitrant pollutants such as pharmaceuticals, flame retardants, persistent organic compounds, anionic surfactants, etc. (Bernhard et al., 2006; Singhal and Perez-Garcia, 2016). Besides, this treatment method also poses several disadvantages which include high footprint and reactor volume, the production of large amount of excess sludge, that requires further treatment and disposal, and the installation of the sedimentation tank for separation of the mixed liquor from the treated effluent. Furthermore, a final disinfection treatment (e.g., UV, ozone, chlorination, etc.) is required for the removal of pathogenic microorganisms.

A more promising alternative for wastewater remediation is the combination of the activated sludge treatment with membrane filtration process. This technology, also known as membrane bioreactor (MBR), differs from CAS since a membrane module is used instead of the secondary clarifier to separate activated sludge from the final effluent (Xing et al., 2000). MBR offers many advantages such as higher effluent quality, smaller footprint and reactor volume, lower energy consumption and less sludge production (Cicek, 2003; Yuniarto et al., 2008). As a result, MBR technology has experienced unprecedented growth in recent years. Its applications have extended widely from treatment of municipal wastewater (Weiss and Reemtsma, 2008; Ma et al., 2013; Zhou et al., 2015) to removal of toxic and hazardous compounds in landfill leachate (Ahmed and Lan, 2012), and industrial wastewaters (Artiga et al., 2005; Yigit et al., 2009; Palogos et al., 2014).

However, an inevitable fouling problem limits the application of this technology into full scale practical operation. The deposition of sludge particles and colloids onto and into the membrane leads to a severe decline of the permeate flux and affects stable operational performance (Kimura et al., 2005). There are several approaches that can reduce fouling in membranes (Naddeo et al., 2015a,b; Scannapieco et al., 2015) but the most common techniques used in MBR technology are the excess aeration and frequent membrane cleaning. However, these methods also result in an increase of energy demand and operating costs as well as reduction of membrane lifespan (Wei C. H. et al., 2011; Zhang et al., 2011; Shi et al., 2014).

Recent advances have demonstrated that the application of an electrical field to membrane bioreactors (electrically enhanced membrane bioreactors or electro membrane bioreactor, eMBR) can effectively reduce fouling (Chen et al., 2007; Akamatsu et al., 2010; Liu et al., 2012a). This method induces electrochemical mechanisms such as electrocoagulation, electroosmosis, and electrophoresis that help in degradation of pollutants and, at the same time, control the mobility, and deposition of foulants onto the membrane surface (Bani-Melhem and Elektorowicz, 2011). Electrocoagulation is the main mechanism influencing the removal of organic compounds with high fouling potential from wastewater. It involves the in situ generation of coagulants from the electrochemical dissolution of immersed sacrificial anodes (usually iron or aluminum) (Figure 1C). Depending on the $\mathrm{pH}$ of the solution, various metal species are produced during electrocoagulation which react with the pollutants leading to the destabilization and aggregation of suspended particles and the precipitation and adsorption of dissolved contaminants (Giwa et al., 2016). Moreover, the applied voltage also allows the negatively charged foulants such as activated sludge and secreted polymers to drift toward the oppositely charged electrode and away from the membrane via electrophoretic motion (Figure 1A) (Chen et al., 2007; Akamatsu et al., 2010, 2012). Consequently, electroosmotic force propels the removal of bound water from the microbial flocs electrical double layer which decreases the sludge specific resistance to filtration hence improving fouling control (Figure 1B) (Ibeid et al., 2013a).

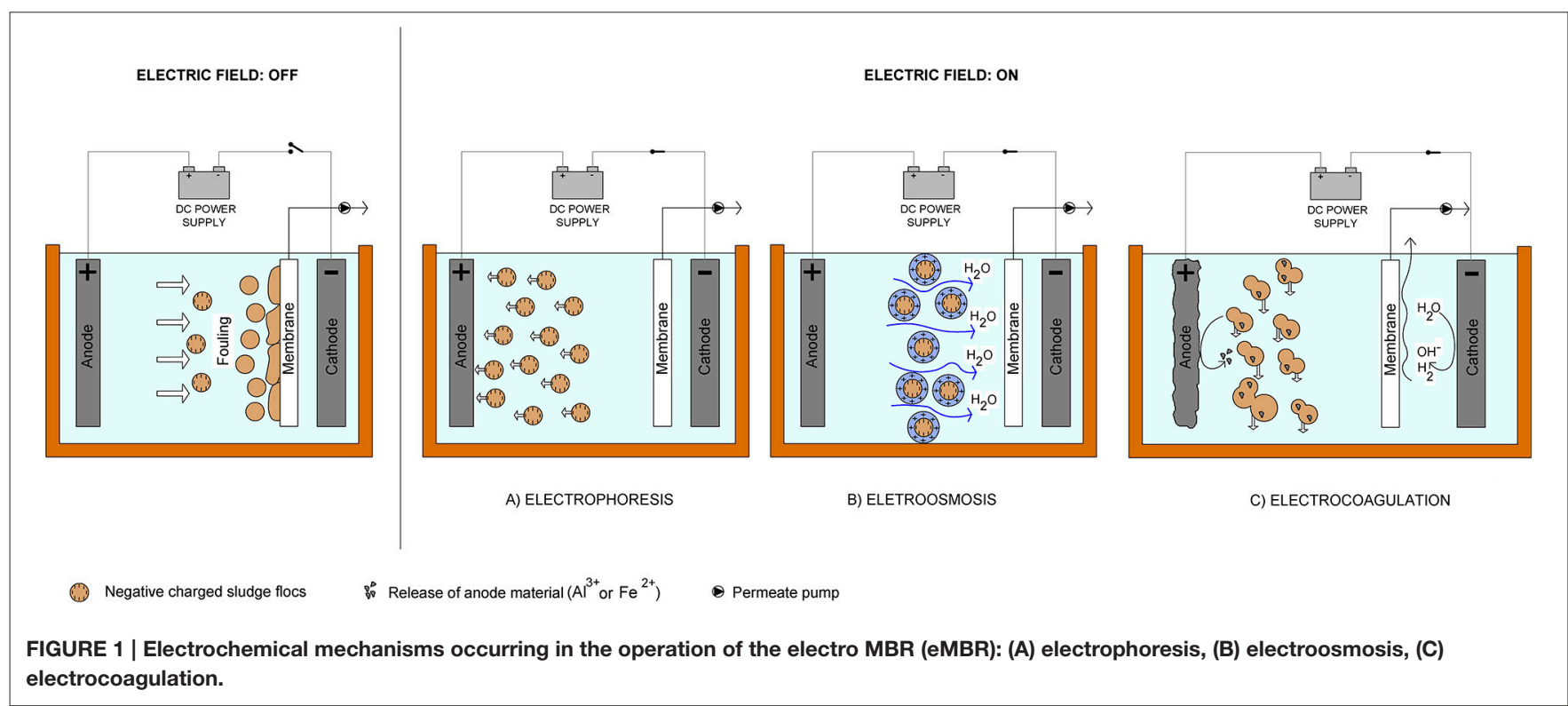

Frontiers in Environmental Science | www.frontiersin.org 
The application of a direct current (DC) field to MBRs has proven to be more effective compared to other fouling control methods, however, it is also associated with high energy consumption and affect bacterial lifespan (Wei V. et al., 2011; Giwa et al., 2015; Zeyoudi et al., 2015). New and cheaper developments suggest that intermittent application of minute electric field also enhances membrane filterability and is similarly effective in controlling fouling as that with continuous DC field (Akamatsu et al., 2010, 2012; Liu et al., 2012a,b). It also minimizes the direct exposure of bacteria to the electric field, hence, reducing the negative effects to microbial community (Akamatsu et al., 2010; Bani-Melhem and Elektorowicz, 2010; Liu et al., 2012a; Hasan et al., 2014). Some studies also focused on extracting internal energy contained in wastewater (e.g., 17.8-28.7 kJ/gCOD) (Heidrich et al., 2011) which can be used to offset the input of external DC field for fouling control. This can be achieved by combining bioelectrochemical systems (BES) with MBRs. Microbial fuel cells (MFCs) and microbial electrolysis cells (MECs) are two types of BES that use exoelectrogenic microbes to produce energy from wastewater by converting biodegradable organic matter directly into electricity, hydrogen, and other valuable products via biological and electrochemical processes (Zhang F. et al., 2014). They are innovative methods for simultaneous renewable energy production and wastewater treatment (Wang et al., 2015). Hybrid systems combining BES with MBR have also been recently investigated for cost-effective wastewater remediation and fouling control (Wang et al., 2012; Liu et al., 2013a, 2014; Li et al., 2014).

This paper critically reviews the combination of electrochemical processes with MBR. This is the first review paper that explores the advantages, the limitations, future challenges, and developments of this hybrid technology in wastewater treatment. The design considerations, applications to different types of wastewater and mechanisms of pollution removal and fouling control using electrically enhanced membrane bioreactor are also discussed.

\section{ELECTRICALLY ENHANCED MEMBRANE BIOREACTOR (eMBR)}

This section is divided into three parts: the first part highlights three of the most important considerations for the design of eMBR which are the main configurations, materials and operating conditions; the second part enumerates the numerous applications of this technology on different types of wastewater and the third discusses the effects of appending electricity on pollutant removal, fouling control, and bacterial activity in an eMBR technology.

\section{Design Considerations Main Configurations}

The main eMBR configurations applied in wastewater treatment can be generally classified into two: (1) External electrochemical unit (usually electrocoagulation unit) preceding a submerged membrane bioreactor (EC-SMBR) (Figure 2A) and (2) submerged membrane electro-bioreactor (SMEBR) (Figure 2B).

EC-SMBR was used by Kim et al. (2010), Bani-Melhem and Smith (2012), and Keerthi et al. (2013) to treat municipal wastewater, actual gray water, and tannery wastewater, respectively. Here, the influent is first treated via electrocoagulation process in a separate unit prior to biological degradation and membrane filtration in a conventional submerged membrane bioreactor (SMBR). This system was developed primarily to enhance the phosphorus removal from wastewater and prevent the applied DC field to have direct contact with the microbial community since it could have inhibitory effects on bacterial activity (Bani-Melhem and Smith, 2012). It was also proven to positively improve chemical oxygen demand (COD) and color removal from tannery wastewater (Keerthi et al., 2013).

In SMEBR, on the other hand, electrochemical processes are integrated with membrane bioreactor by the addition of sacrificial electrodes inside the SMBR. The wastewater first passes through the biological treatment zone for biodegradation,
A

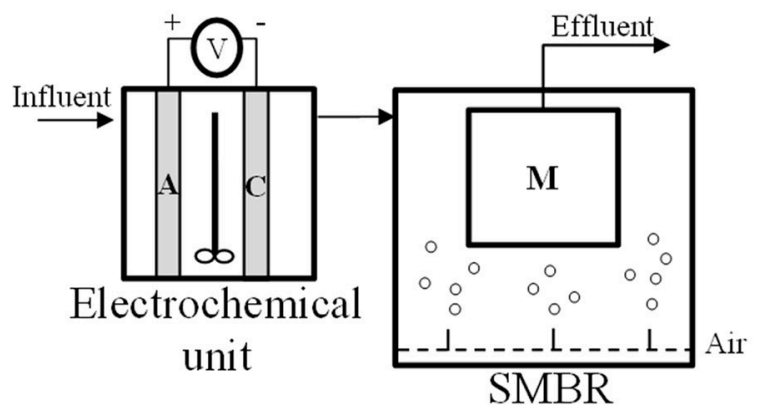

B

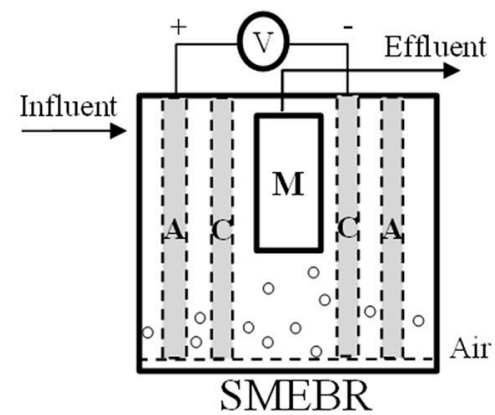

Legend: A- Anode, C-Cathode, M-Membrane module, V-Voltage supply

FIGURE 2 | Main eMBR configurations applied to wastewater treatment: (A) external electrochemical unit (usually electrocoagulation unit) preceding a submerged membrane bioreactor (EC-SMBR), (B) submerged membrane electro-bioreactor (SMEBR). 
that is between the reactor wall and the anode, then across the electrical zone (i.e., between the electrodes) to undergo some electrochemical processes and further degradation, and eventually is filtered out through the membrane module to remove the solids (Hasan et al., 2014) (Figure 1). In some SMEBR studies, the cathode is designed as part of the membrane module [e.g., carbon cloth electrode fabricated with polyvinylidene fluoride (PVDF) membrane or copper wire cathode inside a PP non-woven sheet] or an electrically conductive low- cost membrane is used as the cathode itself [e.g., terylene cloth modified with polypyrrole (Ppy), polyester filter cloth modified with PPy coated graphene (GR/Ppy), or with PPy coated graphene oxide (GO/Ppy)] (Akamatsu et al., 2012; Liu et al., 2012a,b, 2013b; Zhang et al., 2015). Details about membrane and electrode materials are discussed in Section Materials. The resulting effluent quality of eMBR is observed to be better than the EC-SMBR (Tables 1, 2). Moreover, fouling alleviation is further enhanced, as reported in the Section Membrane Fouling Reduction, in this configuration due to the combined efforts of electrocoagulation, electroosmosis, and electrophoresis inside the SMEBR system. A novel design of SMEBR was proposed and developed by Bani-Melhem and Elektorowicz (2010) which consists of cylindrical perforated electrodes immersed inside the bioreactor with a membrane module placed at the center.

Between the two configurations, SMEBR is increasingly becoming more popular and has been utilized in many studies (Bani-Melhem and Elektorowicz, 2010; Ibeid et al., 2013a; Hasan et al., 2014). Since it allows all the three fundamental operations (i.e., biodegradation, electrochemical processes, and membrane filtration) to take place in a single reactor vessel (smaller footprint) and it can be adapted as the most suitable design for large scale applications. Its compact characteristics and high treatment efficiency make SMEBR an economically attractive technology for wastewater treatment.

\section{Materials}

Membrane and electrode materials are equally important in designing eMBR as both can significantly affect the reactor's performance, pollutant removal, and fouling control. The membranes are responsible for the retention of microbes in the reactor which improves biological treatment and for further purification of the resulting effluent via filtration (Giwa et al., 2016). Among the numerous papers available in literature for eMBR, only few studies have been made comparing the different performances of membrane materials and these studies only focused on the effects of the membrane's pore size on fouling. Kim et al. (2010) used two plate type membranes: PVDF (mean pore size: $0.08 \mu \mathrm{m}$ ) and polyethersulfone (PES) (mean pore size: $0.2 \mu \mathrm{m}$ ) in an EC-SMBR system and observed that although both membranes maintained a stable transmembrane pressure (TMP) for a period of 5 months without chemical cleaning, PVDF has better performance, as shown in its lower average TMP $(\mathrm{PVDF}=10 \mathrm{kPa}$ vs. PES $=16 \mathrm{kPa})$ which was attributed to its smaller pore size. Apparently, membranes with large pore sizes are more susceptible to fouling as more smaller particles can migrate, attach and accumulate into the interior surfaces of the pores resulting in pore narrowing and pore blocking and eventually to irreversible fouling (Kim et al., 2010). The same conclusion was reached by Akamatsu et al. (2010) when they used MF-1 $(0.1 \mu \mathrm{m})$ and MF-2 membranes $(0.22 \mu \mathrm{m})$ in eMBR, both membranes were made up of a mixture of cellulose acetate and cellulose nitrate.

The high cost of membrane materials limits eMBR in large scale application. This brought the development of low cost alternatives such as non-wovens, meshes, and filter cloths (Liu et al., 2012a). Though cost efficient, these alternative filters have relatively large pore size and inadequate fouling control. Such constraint has been addressed by a group of researchers modifying low cost filters to improve its effectivity. Liu et al. (2012b) utilized polypyrrole (PPy) modified polyester filter cloth as both the cathode and filtration material in eMBR. Membrane modification was done by liquid and vapor phase polymerization using different concentrations of $\mathrm{FeCl}_{3} \cdot 6 \mathrm{H}_{2} \mathrm{O}(10,20$, and $40 \%)$. Results showed that vapor phased PPy modification with $20 \%$ iron oxidants has substantially increased the membrane's electrical conductivity (lower specific resistances) and a DC field as low as $0.2 \mathrm{~V} / \mathrm{cm}$ is sufficient enough to drive electrostatic repulsion between negatively charged foulants and membrane. This development also paved the way of addressing the issue on the effects of direct application of electric field on bacterial activity which is discussed in Section Microbial Activity. In another study, vapor modified PPy membranes (VPM) were coated by graphene (Gr/PPy) and graphene oxides (GO/PPy) to further enhance their conductivity (Liu et al., 2013b). Graphene and its oxides have unique electronic properties which can be enhanced by coating with polypyrrole (PPy). The electric resistance of GO/PPy modified membrane is $0.71 \mathrm{k} \Omega / \mathrm{cm}$ while for $\mathrm{Gr} / \mathrm{PPy}$ is $0.68 \mathrm{k} \Omega / \mathrm{cm}$. These values are significantly lower compared to $2.03 \mathrm{k} \Omega / \mathrm{cm}$ for PPy modified filter cloth (Liu et al., 2013b). In terms of anti-fouling property, membrane with higher conductivity (i.e., lower electric resistance) shows improvement in permeate flux. Liu et al. (2013b) tested the antifouling performance of $\mathrm{Gr} / \mathrm{PPy}$ and compared it with $\mathrm{PPy}$ modified filter cloth under $1.0 \mathrm{~V} / \mathrm{cm}$ electric field. VPM modified $\mathrm{Gr} / \mathrm{PPy}$ membrane can suppress the fouling more effectively than PPy by increasing the permeate flux and cumulative permeate volume by $20 \%$ (Table 3). PPy modified filter only increases $10 \%$ of cumulative permeate volume (Table 3). Above aforementioned studies have proven that using electrically conductive membranes as the cathode itself was possible and very effective in fouling suppression. Some low-cost membranes used in eMBR and their performances with applied electric field are included in Table 3.

Utilizing better configuration of electrode and membrane materials helps minimize electric energy consumption in fouling reduction. Akamatsu et al. (2012) fabricated a low cost membrane-carbon cloth assembly made of PVDF flatsheet microfiltration (MF) and plain-woven carbon cloth as the membrane and electrodes, respectively. The study successfully demonstrated that upon application of electricity, either continuously or intermittently, the membrane flux always recovers to the initial flux level (Table 3). Liu et al. (2012a) placed copper wires inside the flat sheet membrane module and two stainless mesh anodes outside the module. This configuration ensures constant electrophoretic forces against the deposition 


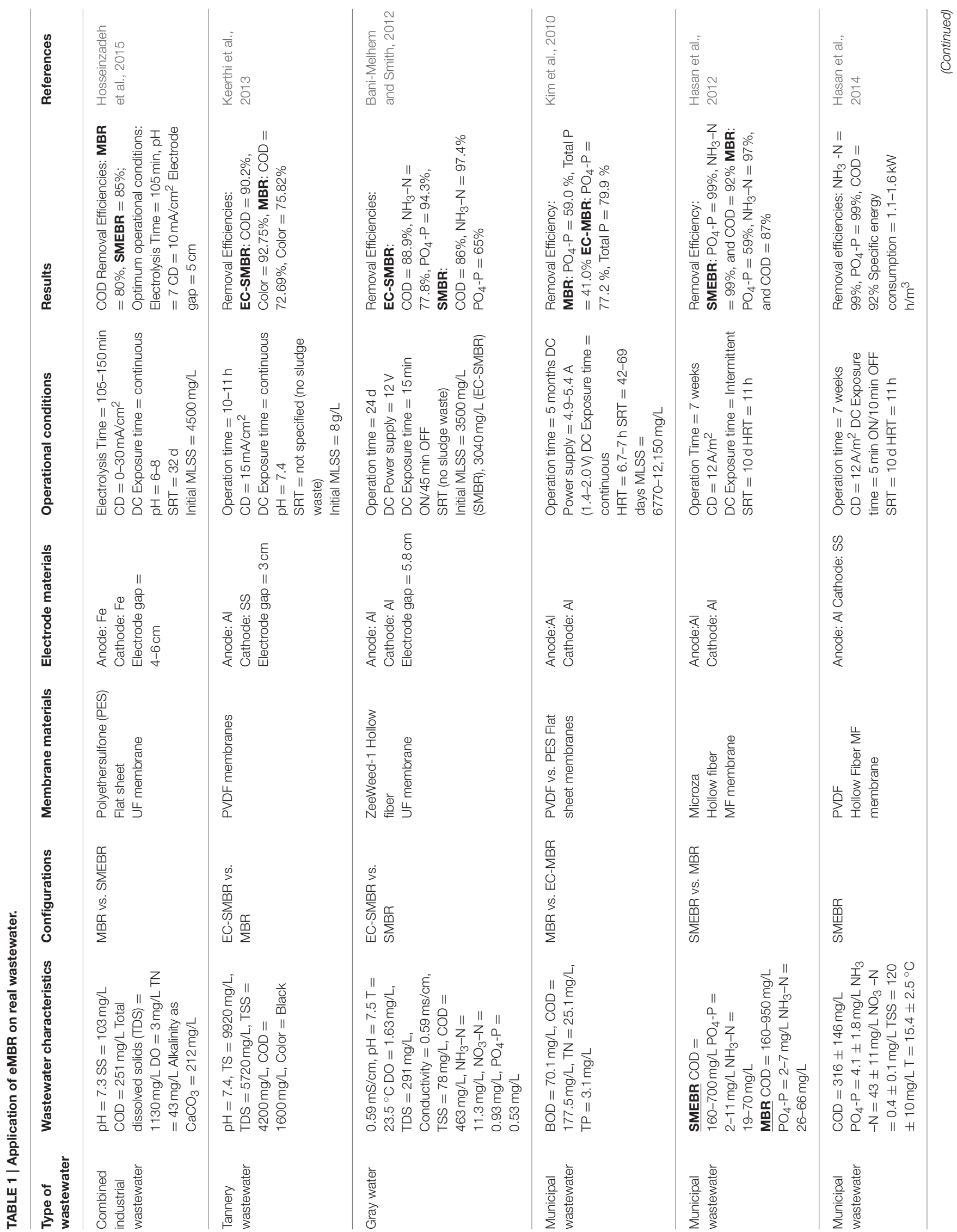




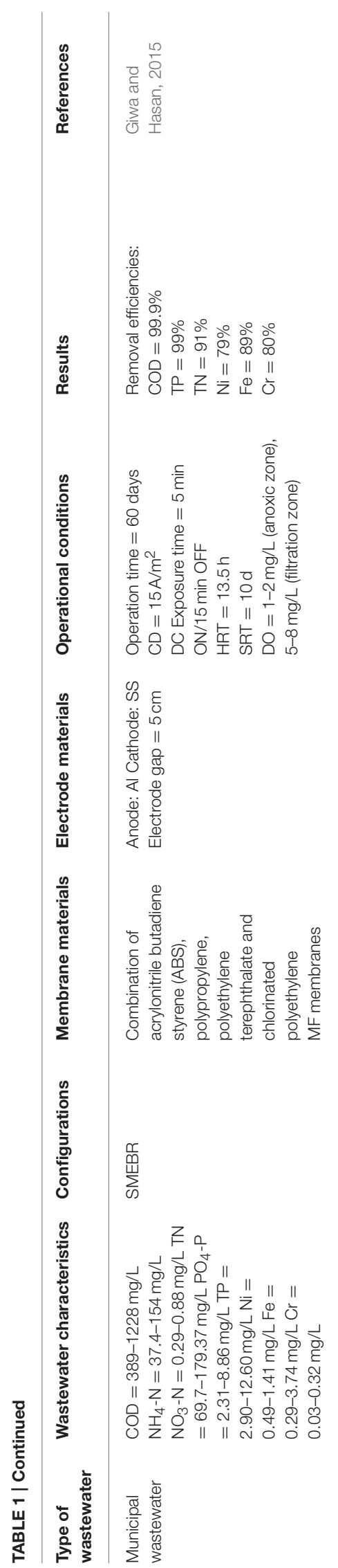

of foulant on the membrane (Table 3). This suggests that inexpensive electrode materials can also be used in eMBR instead of high cost membranes (e.g., PVDF, PES, titanium) which can be a valuable consideration for full scale use.

Anode material is one of the most important parameters in studying eMBR since it significantly affects the current density which is one of the typical performance indicator in any electrochemical system. The two most commonly used anodes in eMBR are aluminum $(\mathrm{Al})$ and iron $(\mathrm{Fe})$ electrodes. Both of them are proven to be useful for pollution removal (Wei et al., 2009) as well as for membrane fouling reduction (Zhang J. et al., 2014). Most importantly, they also serve as micronutrient necessary for microbial growth (Bani-Melhem and Elektorowicz, 2010). However, higher concentrations of dissolved anode materials may create inhibitory effects on bacterial metabolism, hence, electrode impact should be tested according to the applied DC field prior to the eMBR design. There are other anode materials used in eMBR study but this paper focused only on these two sacrificial anodes as they have more benefits than other tested materials (Zhang et al., 2015). The mechanisms of pollutant removal and fouling suppression using these aluminum and iron electrodes are discussed in the succeeding Sections Pollutants Removal and Membrane Fouling Reduction. Aluminum electrodes are preferred compared to iron electrodes due to the higher surface area of aluminum hydroxides, generated from electrocoagulation process, which increases the adsorption capacity (Emamjomeh and Sivakumar, 2009) of soluble compounds and the entrapment of particulate materials.

\section{Operating Conditions}

Operating parameters such as aeration intensity, hydraulic retention time (HRT), sludge retention time (SRT), mixed liquor suspended solids (MLSS), current density (CD), and direct current (DC) exposure time play a vital role in determining both treatment performance and membrane fouling in eMBR. In conventional SMBR, surplus aeration is applied to aid in the scouring of flocs that have adhered on the membrane surfaces for fouling control (Rahimi et al., 2011). In eMBR, excess amount of oxygen is not needed since deposition of foulants onto the membrane surface is controlled by the applied DC field. Studies have shown that the running costs of eMBRs are much lower than MBRs using excess aeration for fouling control (Akamatsu et al., 2010). However, an optimum aeration condition in eMBR is not yet fully studied as it varies accordingly on the design and configuration of the bioreactor. In EC-SMBR, for example, $4.2 \mathrm{~L} / \mathrm{min}$ of compressed air was considered adequate to supply oxygen for microbial incubation, to provide good mixing of the sludge suspension and to create a shear stress for effective scouring of membrane surfaces (Bani-Melhem and Smith, 2012). Zhang et al. (2015), on the other hand, applied an aeration intensity equal to $1 \mathrm{~m}^{3} / \mathrm{h}$ to maintain $2 \mathrm{ppm}$ dissolved oxygen concentration in the SMEBR. Large aeration intensity, greater than $800 \mathrm{~L} / \mathrm{h}$, was observed to be harmful for microbial growth and may cause break down of floc's formation which promotes the release of colloids and solutes resulting in severe pore blocking (Meng et al., 2008). 


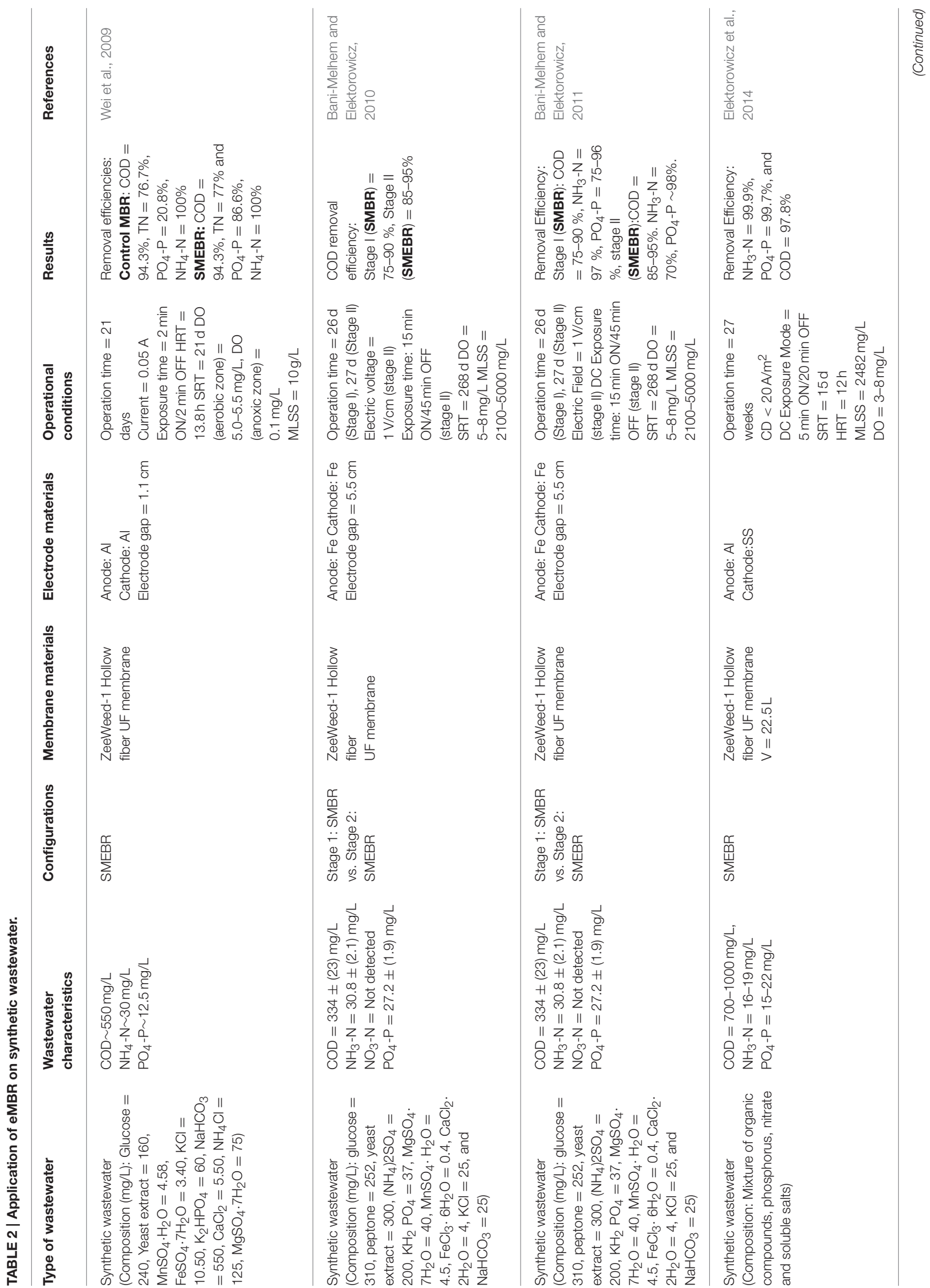




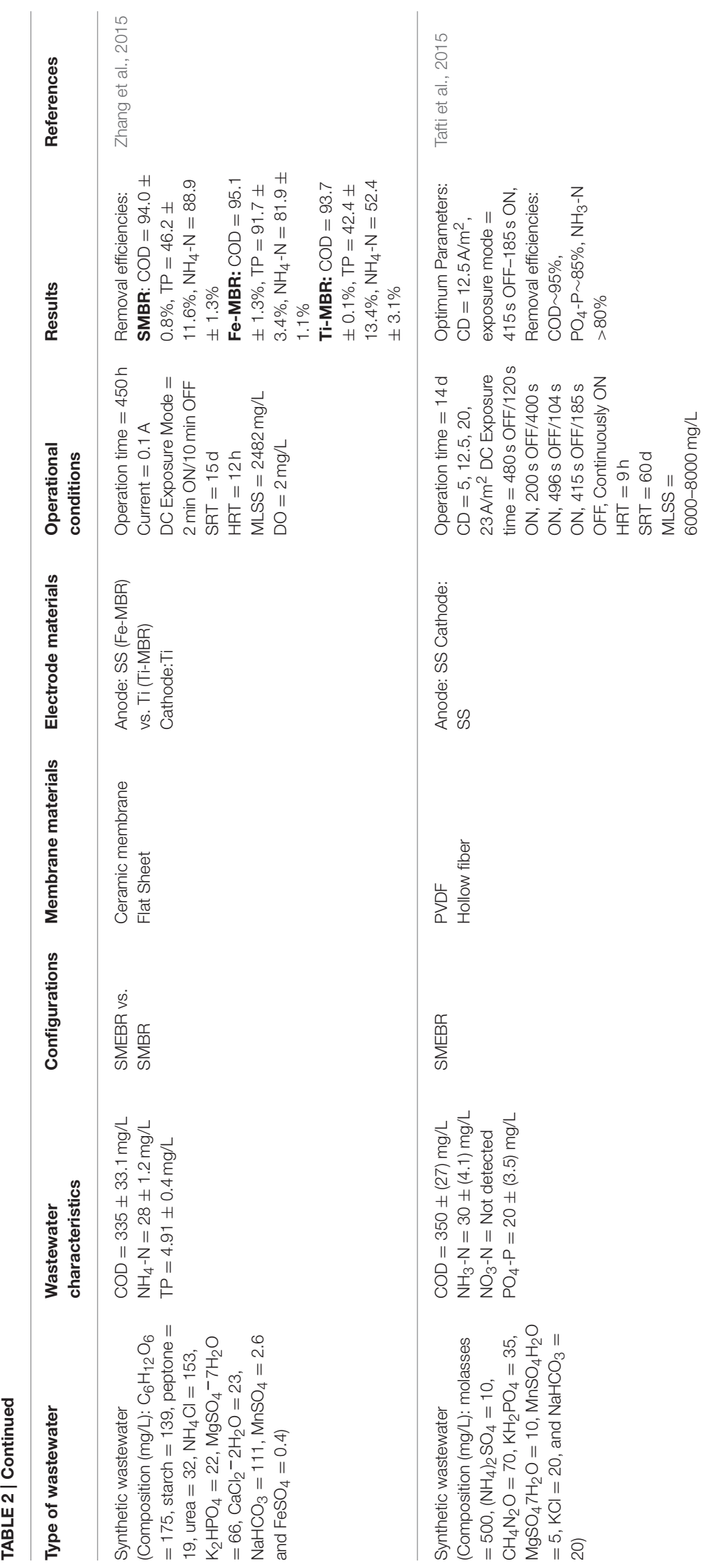


TABLE 3 | Influence of the applied electric field on membrane fouling.

\begin{tabular}{|c|c|c|c|c|}
\hline $\begin{array}{l}\text { Applied electric } \\
\text { field }\end{array}$ & Exposure mode & Membrane material & Effects on membrane fouling & References \\
\hline $0-20 \mathrm{~V} / \mathrm{cm}$ & Continuous ON & $\begin{array}{l}\text { Polypropylene Hollow fibrous } \\
\text { membrane assembly (inner } \\
\text { diameter }=0.32 \mathrm{~mm} \text { ) }\end{array}$ & $\begin{array}{l}\uparrow \text { Electric field }=\uparrow \text { Flux, } \uparrow \text { electrophoresis rate, } \\
\uparrow \text { electroosmosis Optimum electric field }=20 \mathrm{~V} / \mathrm{cm}\end{array}$ & Chen et al., 2007 \\
\hline $1 \mathrm{~V} / \mathrm{cm}$ & Continuous ON & $\begin{array}{l}\text { VPM Gr/Ppy modified polyester } \\
\text { VPM Ppy modified polyester }\end{array}$ & $\begin{array}{l}\text { VPM Gr/Ppy modified polyester: } \\
\uparrow \text { permeate flux by } \sim 20 \% \uparrow \text { cumulative permeate } \\
\text { volume by } 20 \% \\
\text { VPM Ppy modified polyester: } \uparrow \text { cumulative } \\
\text { permeate volume by } \sim 10 \%\end{array}$ & Liu et al., 2013b \\
\hline 0,4 , and $6 \mathrm{~V} / \mathrm{cm}$ & $\begin{array}{l}\text { Continuous ON, Intermittent: } \\
90 \text { s ON/90 s OFF, } 60 \text { s ON/90 s } \\
\text { OFF, } 30 \text { s ON/90 s OFF }\end{array}$ & $\begin{array}{l}\text { Mixture of Cellulose acetate and } \\
\text { cellulose nitrate (MF-1 pore size } \\
=0.1 \mu \mathrm{m}, \text { MF-2 pore size }= \\
0.22 \mu \mathrm{m})\end{array}$ & $\begin{array}{l}\text { Continuous: } \uparrow \text { electric field }=\uparrow \text { Flux, } \uparrow \\
\text { electrostatic repulsion } \\
\text { Intermittent: permeate flux always recovers when } \\
6 \mathrm{~V} / \mathrm{cm} \text { is applied for } 90 \mathrm{~s} \text { due to electrophoretic } \\
\text { force (optimum application }=6 \mathrm{~V} / \mathrm{cm}, 90 \mathrm{~s} \text { ON } / 90 \mathrm{~s} \\
\text { OFF) }\end{array}$ & $\begin{array}{l}\text { Akamatsu et al., } \\
2010\end{array}$ \\
\hline
\end{tabular}

\begin{tabular}{lll}
\hline $5,12.5,20$, and & Continuous ON, Intermittent: & Hollow fiber PVDF membrane \\
$23 \mathrm{~A} / \mathrm{m}^{2}$ & 200 s ON/400 s OFF, 415 s & (pore size $=0.1 \mu \mathrm{m}$ ) \\
& ON/185 s OFF, 480 s ON/120 s & \\
OFF, 496 s ON/104 s OFF & \\
\hline $0,15 \mathrm{~A} / \mathrm{m}^{2}$ & Intermittent: $5 \mathrm{~min}$ ON/20 min & $\begin{array}{l}\text { Ultrafiltration Zeeweed-1 (pore } \\
\text { size }=0.04 \mu \mathrm{m} \text { ) }\end{array}$
\end{tabular}

$\uparrow$ Current Density $=\downarrow$ sludge conductivity, $\uparrow$

Tafti et al., 2015 settleability, $\downarrow$ SVI, $\downarrow$ SMP, $\uparrow$ Flocs size, $\uparrow$ electrophoresis,

\section{SRT $=20 \mathrm{~d}$}

Ibeid et al., 2015

$\downarrow$ SRF $($ MBR $=24 \times 1012 \mathrm{~m} / \mathrm{kg}, \mathrm{SEMBR}=$ $3.2 \times 1012 \mathrm{~m} / \mathrm{kg}) \downarrow \mathrm{SMP}(\mathrm{MBR}=75-135 \mathrm{mg} / \mathrm{L}$, $\mathrm{SEMBR}=40-60 \mathrm{mg} / \mathrm{L}) \downarrow$ bound water $(\mathrm{MBR}=$ $\left.1.2 \mathrm{gH}_{2} \mathrm{O} / \mathrm{g} \mathrm{TS}, \mathrm{SEMBR}=1.2 \mathrm{gH}_{2} \mathrm{O} / \mathrm{g} \mathrm{TS}\right)$ $\downarrow$ VSS/MLSS $(\mathrm{MBR}=0.85, \mathrm{SEMBR}=0.52) \downarrow \mathrm{PSD}$ $(\mathrm{MBR}=200 \mu \mathrm{m}, \mathrm{SEMBR}=400 \mu \mathrm{m}) \downarrow$ Zeta potential $(\mathrm{MBR}=-30$ to $-35 \mathrm{mV}$, SEMBR $=-20$ to $-25 \mathrm{mV}$ )

$\underline{\mathrm{SRT}}=150 \mathrm{~d}$

$\downarrow \mathrm{SRF}(\mathrm{MBR}=688 \times 1012 \mathrm{~m} / \mathrm{kg}, \mathrm{SEMBR}=$ $3.7 \times 1012 \mathrm{~m} / \mathrm{kg}) \downarrow \mathrm{SMP}(\mathrm{MBR}=130-195 \mathrm{mg} / \mathrm{L}$, $\mathrm{SEMBR}=75-85 \mathrm{mg} / \mathrm{L}) \downarrow$ bound water $(\mathrm{MBR}=$ $20 \mathrm{gH}_{2} \mathrm{O} / \mathrm{g} \mathrm{TS}, \mathrm{SEMBR}=6.8 \mathrm{gH}_{2} \mathrm{O} / \mathrm{g} \mathrm{TS}$ ) $\downarrow$ VSS/MLSS (MBR $=0.85$, SEMBR $=0.59) \downarrow P S D$ $(\mathrm{MBR}=200 \mu \mathrm{m}, \mathrm{SEMBR}=400 \mu \mathrm{m}) \downarrow$ Zeta potential $(\mathrm{MBR}=-30$ to $-35 \mathrm{mV}$, SEMBR $=-20$ to $-25 \mathrm{mV}$ )

\begin{tabular}{lll}
\hline $15 \mathrm{~A} / \mathrm{m}^{2}$ & $\begin{array}{l}\text { Intermittent: } 5 \mathrm{~min} \text { ON/20 min } \\
\text { OFF }\end{array}$ & $\begin{array}{l}\text { Hollow fiber PVDF membrane } \\
\text { (pore size }=0.1 \mu \mathrm{m})\end{array}$ \\
\hline 30 and $50 \mathrm{~V} / \mathrm{cm}$ & Intermittent: $4 \mathrm{~min}$ ON/4 min OFF & $\begin{array}{l}\text { PVDF Membrane-Carbon Cloth } \\
\text { assembly (pore size }=0.1 \mu \mathrm{m})\end{array}$
\end{tabular}

$\uparrow$ TMP from 2 to $8 \mathrm{kPa} \downarrow$ Fouling rate by $3 \times$ : $\mathrm{SEMBR}=0.13 \mathrm{kPa} / \mathrm{d}$ vs. $\mathrm{MBR}=0.37 \mathrm{kPa} / \mathrm{d}$

Ibeid et al., 2013a

The flux always recover completely to the initial flux level when $50 \mathrm{~V} / \mathrm{cm}$ is applied. For $30 \mathrm{~V} / \mathrm{cm}$, Akamatsu et al., recovery is not complete. $\uparrow$ Electric field $=\uparrow$ repulsive force acting on the foulant substances at the membrane surface

\begin{tabular}{|c|c|c|}
\hline $\begin{array}{l}0.036 \text { and } \\
0.073 \mathrm{~V} / \mathrm{cm}\end{array}$ & Intermittent ( 5 min ON/1 min OFF) & $\begin{array}{l}\text { Non-woven PP membrane (pore } \\
\text { size }=5 \mu \mathrm{m} \text { ) Terylene Filter cloth } \\
\text { (pore size }=22 \mu \mathrm{m} \text { ) }\end{array}$ \\
\hline
\end{tabular}

Non-woven PP membrane $(0.036 \mathrm{~V} / \mathrm{cm})$ :

$\downarrow$ Irreversible Resistance by $20 \times \downarrow$ flocs size $\downarrow$ EPS concentration by $6-7 \mathrm{mg} / \mathrm{gMLVSS}$

Terylene Filter cloth $(0.073 \mathrm{~V} / \mathrm{cm})$ : $2 \times$ voltage drop is required due to larger pore size and thickness

\begin{tabular}{|c|c|c|c|c|}
\hline $0.2 \mathrm{~V} / \mathrm{cm}$ & Intermittent: 5 min ON/1 min OFF & $\begin{array}{l}\text { Vapor Phased Polymerized } \\
\text { (VPM) Ppy membrane }\end{array}$ & $\begin{array}{l}\uparrow \text { Flux by } 2 \times \uparrow \text { Effluent volume by } 30 \% \text { after } 4 \mathrm{~h} \text { of } \\
\text { filtration }\end{array}$ & Liu et al., 2012b \\
\hline $0.2 \mathrm{~V} / \mathrm{cm}$ & Intermittent: 5 min ON/1 min OFF & Ppy/SDBS modified polyester & $\begin{array}{l}\downarrow \text { Irreversible resistances by } 5 \times \downarrow \text { Total resistances } \\
\text { by } 2 \times \downarrow \text { Deposited sludge in cake layer by } 22 \%\end{array}$ & Liu et al., 2013c \\
\hline
\end{tabular}

$\uparrow$, increase of variable value; $\downarrow$, decrease of variable value; $x$, times. 
The effects of HRT and sludge properties (SRT and MLSS) in wastewater treatment using eMBR were explored by Giwa and Hasan (2015). In their experiments, reduction of effluent characteristics [COD, total nitrogen (TN), and total phosphorus (TP)] were realized at increasing HRT due to more exposure time of reactor content to biodegradation and electrocoagulation. HRT was varied by increasing the influent flow rate from 20 to $50 \mathrm{~L} / \mathrm{d}$. COD and TP concentrations in the effluent were lower at shorter SRT due to the decline in the MLSS concentration, while high TN removal was observed when SRT was increased from 5 to 20 days due to the provision of ample time for the growth of nitrifying bacteria responsible for the biological nitrification processes (Giwa and Hasan, 2015). The values of HRT in some studies range from 6 to $14 \mathrm{~h}$ (Wei et al., 2009; Kim et al., 2010; Elektorowicz et al., 2014; Hasan et al., 2014) while, regarding SRT, it can last up to 268 days (Bani-Melhem and Elektorowicz, 2011) (Tables 1, 2). Longer SRT is one of the many advantages of eMBR over CAS process. Sludge wasting can be minimized, hence, eMBR has lower sludge production.

Meanwhile, the effect of MLSS on fouling control varies in some studies. Giwa et al. (2015) proved that increasing MLSS $(1455-4111 \mathrm{mg} / \mathrm{L})$ causes more severe fouling due to the increase in sludge viscosity leading to higher hydrodynamic force required to propel sludge circulation. Bani-Melhem and Elektorowicz (2011), on the other hand, showed that MLSS concentration within the range of $2100-5000 \mathrm{mg} / \mathrm{L}$ has less effect on membrane fouling. To date, there is no study yet on the optimum range of MLSS in eMBR that would give excellent pollutant removal and fouling minimization.

Current density $(\mathrm{CD}=$ current $[\mathrm{A}] /$ anode electrode area $\left.\left[\mathrm{m}^{2}\right]\right)$ is a crucial factor which affects the performance of the electrochemical treatment in eMBR. It controls the dosing rate of metal ions as well as the gas bubble density that are released in the solution via redox reactions of electrodes (Ibeid et al., 2013b). The higher the current density, the more coagulants are formed in a shorter period of time and the stronger electrokinetic forces are induced between foulants, bulk liquid, and membrane, hence, improving pollutant removal and fouling abatement. Excessive $C D$ also results in waste of energy in the form of heat dissipation inside the reactor (Zhang et al., 2015). At the same time, DC exposure time is also important since both the intensity and application time can significantly influence bacterial community in the eMBR system (Giwa and Hasan, 2015). Optimization of these parameters is, therefore, a must. Tafti et al. (2015) studied the impact of CD ranging from 5 to $23 \mathrm{~A} / \mathrm{m}^{2}$ in combination with different DC exposure modes as reported in Table 2 ( $480 \mathrm{~s}$ OFF/120 s ON, $200 \mathrm{~s} \mathrm{OFF} / 400 \mathrm{~s} \mathrm{ON}$, $496 \mathrm{~s}$ OFF/104 s ON, $415 \mathrm{~s}$ OFF/185 s OFF and continuously ON) on activated sludge properties and pollutant removal efficiencies using synthetic municipal wastewater. Results showed that at higher $\mathrm{CD}\left(>20 \mathrm{~A} / \mathrm{m}^{2}\right)$, eMBR exhibits higher COD, phosphate and ammonia removals as compared to conventional SMBR and that the microbial flocs were able to tolerate the electrical shocks at these values. The optimum conditions observed by Tafti et al. (2015) were $\mathrm{CD}=12.5 \mathrm{~A} / \mathrm{m}^{2}$ and exposure mode equal to $415 \mathrm{~s}$ OFF/ $185 \mathrm{~s}$ ON. Other papers employed CD intensities ranging from 10 to $12 \mathrm{~A} / \mathrm{m}^{2}$ in their eMBR studies and obtained similar results (Hasan et al., 2012, 2014; Hosseinzadeh et al., 2015) (Table 1). Moreover, the amount of DC exposure time used in eMBR primarily depends on the current density and sludge properties (i.e., MLSS). At CD equals to $25 \mathrm{~A} / \mathrm{m}^{2}$ and MLSS below 10,000 mg/L, shorter time-OFF was needed in each electrical cycle while at higher MLSS values, longer time-OFF is required (Ibeid et al., 2013b). The effects of electricity on pollutant removal, fouling control and microbial activity are further discussed in Section Effects of the Electric Field on eMBR Performance.

As mentioned, all of these parameters influence eMBR performance by directly affecting the sludge properties. Therefore, it is important to note that understanding the relationship between these parameters and identifying their appropriate combination, which will depend on the type of wastewater (low, medium, high-strength wastewater) being treated and configuration used, result in an enhancement of eMBR performance.

\section{Application with Different Influent Wastewater}

Due to numerous advantages that the technology provides, eMBR has been used in the treatment of different types of influent wastewater. It has been employed to remove organic substances (COD) and nutrients (nitrogen and phosphorous) as well as color from combined industrial wastewater (Hosseinzadeh et al., 2015), tannery wastewater (Keerthi et al., 2013), and municipal or domestic wastewater (Kim et al., 2010; Bani-Melhem and Smith, 2012; Hasan et al., 2012, 2014). Tables 1, 2 provide a comprehensive summary of the applications of electrically induced membrane bioreactor on real and synthetic wastewater, respectively.

Most investigations of this hybrid reactor were still limited to lab scale reactors fed with synthetic or low-to-medium strength wastewater and only few focuseson pilot scale application. The challenge, therefore, centers on scale-up of this system and its application to wastewater with high pollutant loading (e.g., landfill leachate, food processing wastewater, etc.). Moreover, eMBR could also provide a suitable environment for the biodegradation of emerging contaminants (i.e., endocrine disrupting substances, pharmaceutical products, flame retardants, and personal care products) from water and wastewater streams due to its high solid retention and use of diverse microbial culture.

\section{Effects of the Electric Field on eMBR Performance \\ Pollutants Removal}

Previous studies have reported high satisfactory results in eMBR performance. In fact, removal efficiencies of organic and inorganic compounds in wastewater using eMBR exceeded the performance of conventional MBR systems (Wei et al., 2009; Bani-Melhem and Elektorowicz, 2010, 2011; Kim et al., 2010; Bani-Melhem and Smith, 2012; Hasan et al., 2012; Zhang et al., 2015). Both MBR and eMBR systems exhibit excellent removal of physical impurities i.e., color (>91\%), turbidity (>95\%), and 
suspended solids (100\%) due to the effective solid retention by the membrane module (Bani-Melhem and Smith, 2012). However, in terms of COD, eMBR gives higher removal efficiency (85-98\%) compared to MBR (72-95\%) (Tables 1, 2) which is attributed to the effects of electrochemical processes (i.e., electrocoagulation, electroosmosis, electrophoresis) in addition to biodegradation and membrane filtration (Hosseinzadeh et al., 2015). During electrocoagulation (Figure 1C), various monomeric and polymeric metal complexes are generated from the electrochemical dissolution (electro-oxidation) of sacrificial metal electrodes (aluminum or iron) (Wei et al., 2009). In the case of aluminum anode, $\mathrm{Al}^{3+}$ ions react with $\mathrm{OH}^{-}$ions to form amorphous $\mathrm{Al}(\mathrm{OH})_{3(\mathrm{~s})}$ while for iron, gelatinous iron hydroxide $\mathrm{Fe}(\mathrm{OH})_{2(\mathrm{~s})}$ and/or $\mathrm{Fe}(\mathrm{OH})_{3(\mathrm{~s})}$ is formed in the aqueous stream due to the reaction between $\mathrm{Fe}^{2+}$ and $\mathrm{Fe}^{3+}$ with $\mathrm{OH}^{-}$(Equations 1-8). These metal complexes react with contaminants in the wastewater to form flocs which can both destabilize and aggregate colloidal particles or precipitate and adsorb dissolved compounds (Elabbas et al., 2016). Oxidation and reduction of some pollutants may also be possible which lead to its deposition at the anode and cathode, respectively (Giwa et al., 2016).

For Aluminum:

$$
\begin{aligned}
& \text { At the anode: } \mathrm{Al}_{(\mathrm{s})} \rightarrow \mathrm{Al}^{3+}+3 e^{-} \\
& \text {At the cathode: } 2 \mathrm{H}_{2} \mathrm{O}+2 e^{-} \rightarrow \mathrm{H}_{2(\mathrm{~g})}+2 \mathrm{OH}^{-} \\
& \text {In the solution: } \mathrm{Al}^{3+}+3 \mathrm{OH}^{-} \rightarrow \mathrm{Al}(\mathrm{OH})_{3(\mathrm{~s})}
\end{aligned}
$$

For Iron:

$$
\begin{aligned}
& \text { At the anode }: \mathrm{Fe}_{(\mathrm{s})} \rightarrow \mathrm{Fe}^{2+}+2 e^{-} \\
& \text {At the cathode: } 2 \mathrm{H}_{2} \mathrm{O}+2 e^{-} \rightarrow \mathrm{H}_{2(\mathrm{~g})}+2 \mathrm{OH}^{-} \\
& \text {In the solution: } \mathrm{Fe}^{2+}+2 \mathrm{OH}^{-} \rightarrow \mathrm{Fe}(\mathrm{OH})_{2(\mathrm{~s})}
\end{aligned}
$$

Likewise, eMBR performs better in phosphorus removal than SMBR. EC-SMBR can remove as high as 94.3\% $\mathrm{PO}_{4}^{3-} \mathrm{P}$ (compared to 65\% in SMBR) (Bani-Melhem and Smith, 2012) while SMEBR can remove up to $99 \%(\mathrm{MBR}=59 \%$ removal $)$ (Hasan et al., 2012) from both raw (Table 1) and synthetic wastewaters (Table 2). This is because generated $\mathrm{Al}$ and $\mathrm{Fe}$ coagulants facilitate adsorption of soluble phosphorus in the bioreactor (Kim et al., 2010; Bani-Melhem and Smith, 2012). Biodegradation alone does not adequately eliminate $\mathrm{PO}_{4}^{3-} \mathrm{P}$ from aqueous solution hence the low removal efficiency in conventional MBR (as low as 20.8\%) (Wei et al., 2009). Using aluminum anode, cationic polymers such as $\mathrm{Al}^{3+}$ and $\left[\mathrm{Al}_{6}\left(\mathrm{OH}_{15}\right)\right]^{3+}$ react with phosphate ions to precipitate $\mathrm{AlPO}_{4(\mathrm{~s})}$ and $\mathrm{Al}_{6}\left(\mathrm{OH}_{15}\right) \mathrm{PO}_{4(\mathrm{~s})}$, respectively, according to Equations (7), (8) (Bani-Melhem and Smith, 2012). In the case of sacrificial Fe anode, the iron hydroxides that are formed adsorb the soluble phosphorus and the excess $\mathrm{Fe}^{3+}$ combines with phosphorus ions to form $\mathrm{FePO}_{4(\mathrm{~s})}$ precipitates (Equation 9) (Bani-Melhem and Elektorowicz, 2011).

$$
\begin{aligned}
\mathrm{Al}^{3+}+\mathrm{PO}_{4}{ }^{3-} & \rightarrow \mathrm{AlPO}_{4(\mathrm{~s})} \\
\mathrm{Al}_{6}(\mathrm{OH})_{15}{ }^{3+}+\mathrm{PO}_{4}{ }^{3-} & \rightarrow\left[\mathrm{Al}_{6}(\mathrm{OH})_{15}\right] \mathrm{PO}_{4(\mathrm{~s})} \\
\mathrm{Fe}^{3+}+\mathrm{PO}_{4}{ }^{3-} & \rightarrow \mathrm{FePO}_{4(\mathrm{~s})}
\end{aligned}
$$

Depending on their net surface charge, the pollutants can also migrate and deposit on oppositely charged electrodes via electrophoretic motion upon DC application (Giwa et al., 2015). For example, the deposition of anions on the anode as represented by Equation (10) where $\mathrm{M}^{+}$and $\mathrm{A}^{-}$correspond to metal ions and anion, respectively. In addition, electroosmosis mechanism (Figure 1B) also occurs within the system which enhances dewatering of the smaller floc particles and decreasing specific resistance to filtration (Ibeid et al., 2013a). Heavier flocs that are not adsorbed on the electrode surface settled at the bottom of the reactor as sludge due to gravity and to the gas produced at the electrodes (Giwa et al., 2015).

$$
\mathrm{M}^{+}+\mathrm{A}^{-} \rightarrow \mathrm{MA}+(\mathrm{MA})^{+} \text {or }(\mathrm{MA})^{-}
$$

Treatment efficiencies of ammonia nitrogen $\left(\mathrm{NH}_{3}-\mathrm{N}\right)$ were consistently excellent in conventional MBR ( $\sim 89 \%$ and up) but vary in electro-enhanced MBR (70-100\%) (Tables 1, 2). There are two factors being considered for such results: (1) the application of high DC field and (2) excessive metal ion concentration (Bani-Melhem and Elektorowicz, 2011; Tafti et al., 2015). Nitrifying bacteria, which are responsible for the conversion of ammonia nitrogen $\left(\mathrm{NH}_{3}-\mathrm{N}\right)$ to nitrate nitrogen $\left(\mathrm{NO}_{3}-\mathrm{N}\right)$, are very much sensitive to high voltage. Direct exposure to applied DC $>2.5 \mathrm{~A} / \mathrm{m}^{2}$ was proved to have inhibitory effects in the metabolism of nitrifying bacteria (Li et al., 2001). Furthermore, accumulation of metal ion complexes as a result of electro-dissolution of sacrificial anodes is also detrimental to nitrifying bacteria. Iron complexes, in particular, form a barrier that hinders the transfer of enzymes and nutrients through the microbial cell membrane (Bani-Melhem and Elektorowicz, 2011). This is the reason why ammonia removal using iron and stainless steel anodes are relatively lower (70 and 81.9\%, respectively) (Bani-Melhem and Elektorowicz, 2011; Zhang et al., 2015) as compared when using aluminum anode (98-100\%) (Wei et al., 2009; Hasan et al., 2012; Giwa et al., 2016). Optimization of electrolysis conditions should, therefore, be done so as not to impede biological treatment.

\section{Membrane Fouling Reduction}

Investigation on the influence of appending electricity on fouling control in eMBR was pioneered by Chen et al. (2007). In this study, six different DC field strengths ranging from 0 to $20 \mathrm{~V} / \mathrm{cm}$ were applied and the results showed that better filtrate flux recovery was obtained at higher DC intensity due to the increase in particle electrophoresis. In SMEBR, the movement of the suspended particles and the water during membrane filtration can be controlled by the applied electrical field. Major foulants in wastewater usually possess negative surface charge and upon DC application, electrophoresis force counteracts permeationinduced deposition of these foulants away from the membrane surface and toward the electrode of opposite charge (anode) (Figure 1A) (Wei et al., 2009). On the other hand, the bulk liquid which is commonly positively charged is drifted toward the cathode then flows to the membrane facilitating the filtration, a process called electroosmosis (Figure 1B). Electroosmosis, thus, removes bound water from the microbial flocs enhancing sludge 
dewaterability and decreasing the specific resistance to filtration (Ibeid et al., 2013a). Specific cake resistance to filtration and modified fouling index were observed to decrease by 82 and $81 \%$, respectively, when $12 \mathrm{~A} / \mathrm{m}^{2}$ current density was applied to eMBR in the treatment of raw municipal wastewater (Hasan et al., 2014).

Application of electric field for membrane fouling suppression does not only control the movement of charged particles and bulk liquid, it also modifies the sludge properties through the electrocoagulation process (Figure 1C) (Hasan et al., 2014). The use of sacrificial anodes releases metal ions which precipitate or adsorb negatively charged foulants [i.e., extracellular polymeric substances (EPS), soluble microbial products (SMP)] and facilitates formation of larger flocs which drives the particle backtransport from the membrane surface to the bulk solution (Ibeid et al., 2013a). In a study conducted by Zhang et al. (2015), two types of anode materials were used: stainless steel (Fe-MBR) and titanium (Ti-MBR). Between the two, Fe-MBR showed better fouling mitigation performance than the Ti-MBR due to the combined action of electric field force induced backwash (electrophoresis) and the formation of iron coagulants which reduced the SMP concentration (electrocoagulation). Titanium mesh anodes used in Ti-MBR were inactive metal hence it did not release any coagulant ions and fouling control relied mostly on the magnitude of electric field applied (Zhang et al., 2015). Moreover, Kim et al. (2010) proved that electrocoagulation does not only effectively removed phosphorus by precipitating $\mathrm{AlPO}_{4(\mathrm{~s})}$ crystals but these precipitates are also capable of adsorbing EPS. Hosseinzadeh et al. (2015) attributed the lower tansmembrane pressure (TMP) and sludge volume index (SVI) to electrocoagulation in SMEBR. In EC-SMBR, membrane fouling was reduced by $13 \%$ due to the electrocoagulation pre-treatment (Bani-Melhem and Smith, 2012).

Nevertheless, it should be noted that energy consumption and operational cost will obviously be affected by high electricity requirements and, therefore, must be reduced. Some researchers studied the use of intermittent application of minute electric field for effective fouling control and possible energy savings. Table 3 summarizes the different studies that investigates effects of continuous and intermittent application of electric field on membrane fouling. Akamatsu et al. (2010) developed a novel fouling suppression system in MBRs which controls the motion of activated sludge by applying electric current only when the permeate flux has drastically declined due to membrane fouling. By switching on and off every $90 \mathrm{~s}$, electric field strength of $6 \mathrm{~V} / \mathrm{cm}$ facilitates detachment of foulant activated sludge from the surface of the membrane thus significantly improved the average permeate flux (Figure 1A). Upon cost estimation, about half of the energy requirements were saved using this fouling suppression system. In another experiment, Akamatsu et al. (2012) investigated the performance of MBR on fouling suppression by applying 50 and $33 \mathrm{~V} / \mathrm{cm}$ electric field at a $4 \mathrm{~min}$ $\mathrm{ON} / 4$ min OFF cycle directly on the membrane cathode made of carbon cloth. The results showed that the flux always recovered to the initial flux level when the electric field was $\mathrm{ON}$ and at voltage gradient applied equal to $50 \mathrm{~V} / \mathrm{cm}$. This proved that higher electric field intensity means stronger repulsive force between the foulants and the membrane surfaces enhancing the fouling control (Akamatsu et al., 2012). A minute electric field, $0.2 \mathrm{~V}(0.036 \mathrm{~V} / \mathrm{cm})$ and $0.4 \mathrm{~V}(0.073 \mathrm{~V} / \mathrm{cm})$ were applied by Liu et al. (2012a) using a low cost, micro-porous PP non-woven sheet and a terylene filter cloth. For both membranes, application of either 0.2 or $0.4 \mathrm{~V}$ electric field causes increase in permeate flux, enhancement of microbial growth and activity, decrease of filtration resistance and reduction of sludge EPS content which all contributed to fouling control.

\section{Microbial Activity}

Like any other biological wastewater treatment processes, eMBR relies mostly on the mixed microorganisms present in the system. The ability of bacterial community to effectively degrade organic matter (COD) and nutrients $(\mathrm{N}$ and $\mathrm{P}$ ) from raw wastewater makes biological process the most widely used treatment method. Therefore, integrating electrochemical technologies with biological treatment should take into consideration the effects of electricity on bacterial viability.

Microbial analyses have revealed that a stressor such as strong electric current provides negative impact on the microbial properties (i.e., metabolism, physiology, shape, and mobility) (Wei V. et al., 2011). Increasing intensity of electric field (DC $>2.5 \mathrm{~A} / \mathrm{m}^{2}$ ) decreases nitrification rate by $20 \%$ (Li et al., 2001). As a result, low ammonia removal is observed due to the inhibition of nitrobacteria and denitrifying bacteria by large voltage (Bani-Melhem and Elektorowicz, 2011; Bani-Melhem and Smith, 2012; Hasan et al., 2012). Moreover, at higher voltage, breakage of bacterial cells and production of SMP are observed to occur which increases fouling (Zhang et al., 2015). Wei V. et al. (2011) proved that increasing DC intensity $(6.2,12.3$, and $24.7 \mathrm{~A} / \mathrm{m}^{2}$ ) also increases $\mathrm{pH}$ (from nearly neutral to around $\mathrm{pH}$ 10) of electrolytic biomass fluid causing 10, 15, and 29\% death percentage, respectively.

It should be noted that beneficial effects can also be achieved in applying minute electric field in eMBR system. Low voltage $(0.036-0.073 \mathrm{~V} / \mathrm{cm})$ promotes the growth of filamentous bacteria which are proven to improve sludge filterability (Liu et al., 2012a). Intermittent application prevents prolonged direct contact between electric field and microbial community hence minimizing the negative effects of high DC field. To date, there are no studies yet on the optimal electric field suitable for enhancing bacterial activity in an eMBR application.

\section{CONCLUSIONS}

Membrane fouling is a major limitation in MBR operation that should be resolved. Among the different fouling control techniques, integration of electrochemical processes into MBR seems to be a promising method. Electrochemical phenomena such as electrocoagulation, electroosmosis and electrophoresis are the main mechanisms of membrane fouling control in eMBR. It also enhances pollutant removal. However, direct application of electric field to MBRs incurs high energy consumption and has negative effects on bacterial viability which is responsible for the biodegradation of the organic pollutants. Optimum configuration of electric field helps to reduce energy consumption while simultaneously reducing 
inadvertent interferences with eMBR performance. This can be done by using better configuration of electrode and membrane materials and intermittent application of low or moderate electric field.

The combination of electrochemical processes with MBR processes is still in its infancy stage, with a small number of scientific papers published during the last decade. This review focused only on those publications with international significance. The studies on eMBR are limited to bench or pilot scale reactor fed with real or synthetic wastewater. Large scale applications are not reported. Optimization study, modeling and cost benefit analysis between MBR and eMBR are, therefore, useful for scaling up the system. Moreover, treatment of high strength industrial wastewater and the removal of emerging contaminants through eMBRs have not been yet highly explored. There are numerous already published papers regarding the effective removal of these contaminants by electrochemical processes or MBR, but not by the combined process. Moreover, the potential of this combined system as an efficient technology for biohydrogen production, due to hydrogen ions reduction at

\section{REFERENCES}

Ahmed, F. N., and Lan, C. Q. (2012). Treatment of landfill leachate using membrane bioreactors: a review. Desalination 287, 41-54. doi: 10.1016/j.desal.2011.12.012

Akamatsu, K., Lu, W., Sugawara, T., and Nakao, S. (2010). Development of a novel fouling suppression system in membrane bioreactors using an intermittent electric field. Water Res. 44, 825-830. doi: 10.1016/j.watres.2009.10.026

Akamatsu, K., Yoshida, Y., Suzaki, T., Sakai, Y., Nagamoto, H., and Nakao, S. (2012). Development of a membrane - carbon cloth assembly for submerged membrane bioreactors to apply an intermittent electric field for fouling suppression. Sep. Purif. Technol. 88, 202-207. doi: 10.1016/j.seppur.2011.12.031

Artiga, P., Ficara, E., Malpei, F., Garrido, J. M., and Méndez, R. (2005). Treatment of two industrial wastewaters in a submerged membrane bioreactor. Desalination 179, 161-169. doi: 10.1016/j.desal.2004.11.064

Ballesteros, F. Jr., Vuong, T. H., Secondes, M. F., and Tuan, P.D. (2016). Removal efficiencies of constructed wetland and efficacy of plant on treating benzene. Sustain. Environ. Res. 26, 93-96. doi: 10.1016/j.serj.2015.10.002

Bani-Melhem, K., and Elektorowicz, M. (2010). Development of a novel submerged membrane electro-bioreactor (SMEBR): performance for fouling reduction. Environ. Sci. Technol. 44, 3298-3304. doi: 10.1021/es902145g

Bani-Melhem, K., and Elektorowicz, M. (2011). Performance of the submerged membrane electro-bioreactor (SMEBR) with iron electrodes for wastewater treatment and fouling reduction. J. Membr. Sci. 379, 434-439. doi: 10.1016/j.memsci.2011.06.017

Bani-Melhem, K., and Smith, E. (2012). Grey water treatment by a continuous process of an electrocoagulation unit and a submerged membrane bioreactor system. Chem. Eng. J. 198-199, 201-210. doi: 10.1016/j.cej.2012.05.065

Bernhard, M., Müller, J., and Knepper, T. P. (2006). Biodegradation of persistent polar pollutants in wastewater: comparison of an optimised labscale membrane bioreactor and activated sludge treatment. Water Res. 40, 3419-3428. doi: 10.1016/j.watres.2006.07.011

Cesaro, A., Naddeo, V., and Belgiorno, V. (2013). Wastewater treatment by combination of advanced oxidation processes and conventional biological systems. J. Bioremed. Biodeg. 4:208. doi: 10.4172/2155-6199.1000208

Chen, J., Yang, C., Zhou, J., and Wang, X. (2007). Study of the influence of the electric field on membrane flux of a new type of membrane bioreactor. Chem. Eng. J. 128, 177-180. doi: 10.1016/j.cej.2006.10.010

Cicek, N. (2003). A review of membrane bioreactor and their potential application in the treatment of agricultural wastewater. Can. Biosyst. Eng. 45, 637-649. the cathode side, has not been yet investigated. Therefore, further studied could be focused on the combination of MECs with MBR through the operation of the electro MBR at anaerobic conditions for the production of renewable energy.

\section{AUTHOR CONTRIBUTIONS}

VN and VB developed the research idea and planned activities. $\mathrm{BE}$ and $\mathrm{LB}$ prepared the manuscript. $\mathrm{VN}, \mathrm{VB}, \mathrm{MD}$ and $\mathrm{FB}$ reviewed the final draft and supervised the work.

\section{ACKNOWLEDGMENTS}

The authors gratefully thank the Department of Science and Technology-Engineering Research Development and Technology (ERDT-DOST), the University of the PhilippinesDiliman, and the Sanitary Environmental Engineering Division (SEED) of the University of Salerno in Italy for the Ph.D. Sandwich program and research funds. Research activities were partially funded by the FARB project of the University of Salerno.

de Luna, M. D. G., Warmadewanthi and Liu, J. C. (2009). Combined treatment of polishing wastewater and fluoride-containing wastewater from a semiconductor manufacturer. Colloids Surf. A 347, 64-68. doi: 10.1016/j. colsurfa.2008.12.006

Elabbas, S., Ouazzani, N., Mandi, L., Berrekhis, F., Perdicakis, M., Pontvianne, S., et al. (2016). Treatment of highly concentrated tannery wastewater using electrocoagulation: influence of the quality of aluminium used for the electrode. J. Hazard. Mater. 319, 69-77. doi: 10.1016/j.jhazmat.2015.12.067

Elektorowicz, M., Arian, Z., and Ibeid, S. (2014). "Submerged membrane electrobioreactor for water recovery," in Membranes and Membrane Processes in Environmental Protection, Vol. 119, eds M. Bodzek and J. Pelczar (Monographs of the Environmental Engineering Committee, Polish Academy of Sciences), 93-98.

Emamjomeh, M. M., and Sivakumar, M. (2009). Review of pollutants removed by electrocoagulation and electrocoagulation/flotation processes. J. Environ. Manage. 90, 1663-1679. doi: 10.1016/j.jenvman.2008.12.011

Giwa, A., Ahmed, I., and Hasan, S. W. (2015). Enhanced sludge properties and distribution study of sludge components in electrically-enhanced membrane bioreactor. J. Environ. Manage. 159, 78-85. doi: 10.1016/j.jenvman.2015.05.035

Giwa, A., Daer, S., Ahmed, I., Marpu, P. R., and Hasan, S. W. (2016). Experimental investigation and artificial neural networks ANNs modeling of electricallyenhanced membrane bioreactor for wastewater treatment. J. Water Process Eng. 11, 88-97. doi: 10.1016/j.jwpe.2016.03.011

Giwa, A., and Hasan, S. W. (2015). Theoretical investigation of the influence of operating conditions on the treatment performance of an electrically-induced membrane bioreactor. J. Water Process Eng. 6, 72-82. doi: 10.1016/j.jwpe.2015. 03.004

Hasan, S. W., Elektorowicz, M., and Oleszkiewicz, J. A. (2012). Correlations between trans-membrane pressure (TMP) and sludge properties in submerged membrane electro-bioreactor (SMEBR) and conventional membrane bioreactor (MBR). Bioresour. Technol. 120, 199-205. doi: 10.1016/j.biortech. 2012.06.043

Hasan, S. W., Elektorowicz, M., and Oleszkiewicz, J. A. (2014). Start-up period investigation of pilot-scale submerged membrane electro-bioreactor (SMEBR) treating raw municipal wastewater. Chemosphere 97, 71-77. doi: 10.1016/j.chemosphere.2013.11.009

Heidrich, E. S., Curtis, T. P., and Dolfing, J. (2011). Determination of the internal chemical energy of wastewater. Environ. Sci. Technol. 45, 827-832. doi: 10.1021/es103058w

Hosseinzadeh, M., Bidhendi, G. N., Torabian, A., Mehrdadi, N., and Pourabdullah, M. (2015). A new flat sheet membrane bioreactor hybrid system for advanced 
treatment of effluent, reverse osmosis pretreatment and fouling mitigation. Bioresour. Technol. 192, 177-184. doi: 10.1016/j.biortech.2015.05.066

Ibeid, S., Elektorowicz, M., and Oleszkiewicz, J. A. (2013a). Novel electrokinetic approach reduces membrane fouling. Water Res. 47, 6358-6366. doi: 10.1016/j.watres.2013.08.007

Ibeid, S., Elektorowicz, M., and Oleszkiewicz, J. A. (2013b). Modification of activated sludge properties caused by application of continuous and intermittent current. Water Res. 47, 903-910. doi: 10.1016/j.watres.2012.11.020

Ibeid, S., Elektorowicz, M., and Oleszkiewicz, J. A. (2015). Electro-conditioning of activated sludge in a membrane electro-bioreactor for improved dewatering and reduced membrane fouling. J. Membr. Sci. 494, 136-142. doi: 10.1016/j. memsci.2015.07.051

Keerthi S. V., Mahalakshmi, M., and Balasubramanian, N. (2013). Development of hybrid membrane bioreactor for tannery effluent treatment. Desalination 309, 231-236. doi: 10.1016/j.desal.2012.10.014

Kim, H. G., Jang, H. N., Kim, H. M., Lee, D. S., and Chung, T. H. (2010). Effect of an electro phosphorous removal process on phosphorous removal and membrane permeability in a pilot-scale MBR. Desalination 250, 629-633. doi: 10.1016/j.desal.2009.09.038

Kimura, K., Yamato, N., Yamamura, H., and Watanabe, Y. (2005). Membrane fouling in pilot-scale membrane bioreactors (MBRs) treating municipal wastewater. Environ. Sci. Technol. 39, 6293-6299. doi: 10.1021/es0502425

Li, X. G., Cao, H. B., Wu, J. C., and Yu, K.T. (2001). Inhibition of the metabolism of nitrifying bacteria by direct electric current. Biotechnol. Lett. 23, 705-709. doi: 10.1023/A:1010346501857

Li, Y., Liu, L., Liu, J., Yang, F., and Ren, N. (2014). PPy/AQS (9, 10-anthraquinone2-sulfonic acid) and PPy/ARS (Alizarin Red's) modified stainless steel mesh as cathode membrane in an integrated MBR/MFC system. Desalination 349, 94-101. doi: 10.1016/j.desal.2014.06.027

Liu, J., Liu, L., Gao, B., and Yang, F. (2013a). Integration of bio-electrochemical cell in membrane bioreactor for membrane cathode fouling reduction through electricity generation. J. Membr. Sci. 430, 196-202. doi: 10.1016/j.memsci.2012. 11.046

Liu, J., Liu, L., Gao, B., Yang, F., Crittenden, J., and Ren, N. (2014). Integration of microbial fuel cell with independent membrane cathode bioreactor for power generation, membrane fouling mitigation and wastewater treatment. Int. J. Hydrog. Energy 39, 17865-17872. doi: 10.1016/j.ijhydene.2014. 08.123

Liu, L., Liu, J., Bo, G., Yang, F., Crittenden, J., and Chen, Y. (2013c). Conductive and hydrophilic polypyrrole modified membrane cathodes and fouling reduction in MBR. J. Membr. Sci. 429, 252-258. doi: 10.1016/j.memsci.2012. 11.066

Liu, L., Liu, J., Gao, B., and Yang, F. (2012a). Minute electric field reduced membrane fouling and improved performance of membrane bioreactor. Sep. Purif. Technol. 86, 106-112. doi: 10.1016/j.seppur.2011.10.030

Liu, L., Liu, J., Gao, B., Yang, F., and Chellam, S. (2012b). Fouling reductions in a membrane bioreactor using an intermittent electric field and cathodic membrane modified by vapor phase polymerized pyrrole. J. Membr. Sci. 394-395, 202-208. doi: 10.1016/j.memsci.2011.12.042

Liu, L., Zhao, F., Liu, J., and Yang, F. (2013b). Preparation of highly conductive cathodic membrane with graphene (oxide)/PPy and the membrane antifouling property in filtrating yeast suspensions in EMBR. J. Membr. Sci. 437, 99-107. doi: 10.1016/j.memsci.2013.02.045

Ma, D., Gao, B., Hou, D., Wang, Y., Yue, Q., and Li, Q. (2013). Evaluation of a submerged membrane bioreactor (SMBR) coupled with chlorine disinfection for municipal wastewater treatment and reuse. Desalination 313, 134-139. doi: 10.1016/j.desal.2012.12.016

Meng, F., Yang, F., Shi, B., and Zhang, H. (2008). A comprehensive study on membrane fouling in submerged membrane bioreactors operated under different aeration intensities. Sep. Purif. Technol. 59, 91-100. doi: 10.1016/j. seppur.2007.05.040

Naddeo, V., Belgiorno, V., Borea, L., Secondes, M. F. N., and Ballesteros, F. Jr. (2015a). Control of fouling formation in membrane ultrafiltration by ultrasound irradiation. Environ. Technol. 36, 1299-1307. doi: 10.1080/09593 330.2014.985731

Naddeo, V., Borea, L., and Belgiorno, V. (2015b). Sonochemical control of fouling formation in membrane ultrafiltration of wastewater: Effect of ultrasonic frequency. J. Water Process Eng. 8, e92-e97. doi: 10.1016/j.jwpe.2014.12.005
Naddeo, V., Rizzo, L., and Belgiorno, V. (2011). Water, Wastewater and Soil Treatment by Advanced Oxidation Processes. Fisciano, SA. Available online at: www.Lulu.com

Palogos, I., Babatsouli, P., Costa, C., and Kalogerakis, N. (2014). Computer simulation of a submerged membrane bioreactor treating high COD industrial wastewater. Front. Environ. Sci. 2:30. doi: 10.3389/fenvs.2014.00030

Rahimi, Y., Torabian, A., Mehrdadi, N., Habibi-rezaie, M., Pezeshk, H., and Nabibidhendi, G. R. (2011). Optimizing aeration rates for minimizing membrane fouling and its effect on sludge characteristics in a moving bed membrane bioreactor. J. Hazard. Mater. 186, 1097-1102. doi: 10.1016/j.jhazmat.2010. 11.117

Scannapieco, D., Naddeo, V., and Belgiorno, V. (2015). Control of fouling in MBRs through nanospheres addition. Desalin. Water Treat. 55, 702-711. doi: 10.1080/19443994.2014.942382

Secondes, M. F. N., Naddeo, V., Belgiorno, V., and Ballesteros, F. Jr., (2014). Removal of emerging contaminants by simultaneous application of membrane ultrafiltration, activated carbon adsorption, and ultrasound irradiation. J. Hazard. Mater. 264, 342-349. doi: 10.1016/j.jhazmat.2013.11.039

Shi, X., Tal, G., Hankins, N. P., and Gitis, V. (2014). Fouling and cleaning of ultrafiltration membranes: a review. J. Water Process Eng. 1, 121-138. doi: 10.1016/j.jwpe.2014.04.003

Singhal, N., and Perez-Garcia, O. (2016). Degrading organic micropollutants: the next challenge in the evolution of biological wastewater treatment processes. Front. Environ. Sci. 4:36. doi: 10.3389/fenvs.2016.00036

Tafti, A. D., Seyyed Mirzaii, S. M., Andalibi, M. R., and Vossoughi, M. (2015). Optimized coupling of an intermittent DC electric field with a membrane bioreactor for enhanced effluent quality and hindered membrane fouling. Sep. Purif. Technol. 152, 7-13. doi: 10.1016/j.seppur.2015. 07.004

Wang, H., Luo, H., Fallgren, P. H., Jin, S., and Ren, Z. J. (2015). Bioelectrochemical system platform for sustainable environmental remediation and energy generation. Biotechnol. Adv. 33, 317-334. doi: 10.1016/j.biotechadv.2015. 04.003

Wang, Y. P., Liu, X. W., Li, W. W., Li, F., Wang, Y. K., Sheng, G. P., et al. (2012). A microbial fuel cell-membrane bioreactor integrated system for cost-effective wastewater treatment. Appl. Energy 98, 230-235. doi: 10.1016/j.apenergy.2012.03.029

Wei, C. H., Huang, X., Ben Aim, R., Yamamoto, K., and Amy, G. (2011). Critical flux and chemical cleaning-in-place during the long-term operation of a pilotscale submerged membrane bioreactor for municipal wastewater treatment. Water Res. 45, 863-871. doi: 10.1016/j.watres.2010.09.021

Wei, V., Elektorowicz, M., and Oleszkiewicz, J. A. (2011). Influence of electric current on bacterial viability in wastewater treatment. Water Res. 45, 5058-5062. doi: 10.1016/j.watres.2011.07.011

Wei, V., Oleszkiewicz, J. A., and Elektorowicz, M. (2009). Nutrient removal in an electrically enhanced membrane bioreactor. Water Sci. Technol. 60, 3159-3163. doi: 10.2166 /wst.2009.625

Weiss, S., and Reemtsma, T. (2008). Membrane bioreactors for municipal wastewater treatment - A viable option to reduce the amount of polar pollutants discharged into surface waters? Water Res. 42, 3837-3847. doi: 10.1016/j.watres.2008.05.019

Xing, C., Tardieu, E., Qian, Y., and Wen, X. (2000). Ultrafiltration membrane bioreactor for urban wastewater reclamation. J. Membr. Sci. 177, 73-82. doi: 10.1016/S0376-7388(00)00452-X

Yigit, N. O., Uzal, N., Koseoglu, H., Harman, I., Yukseler, H., Yetis, U., et al. (2009). Treatment of a denim producing textile industry wastewater using pilot-scale membrane bioreactor. Desalination 240, 143-150. doi: 10.1016/j.desal.2007.11.071

Yuniarto, A., Ujang, Z., and Noor, Z. Z. (2008). Performance of bio-fouling reducers in aerobic submerged membrane bioreactor for palm oil mill effluent treatment performance of bio-fouling reducers in aerobic submerged membrane bioreactor for palm oil mill effluent treatment. Management 49, 555-566.

Zeyoudi, M., Altenaiji, E., Ozer, L. Y., Ahmed, I., Yousef, A. F., and Hasan, S. W. (2015). Impact of continuous and intermittent supply of electric field on the function and microbial community of wastewater treatment electrobioreactors. Electrochim. Acta 181, 271-279. doi: 10.1016/j.electacta.2015. 04.095 
Zhang, F., Li, J., and He, Z. (2014). A new method for nutrients removal and recovery from wastewater using a bioelectrochemical system. Bioresour. Technol. 166, 630-634. doi: 10.1016/j.biortech.2014.05.105

Zhang, J., Satti, A., Chen, X., Xiao, K., Sun, J., Yan, X., et al. (2015). Lowvoltage electric field applied into MBR for fouling suppression: performance and mechanisms. Chem. Eng. J. 273, 223-230. doi: 10.1016/j.cej.2015.03.044

Zhang, J., Xiao, K., Liang, P., Waite, T. D., and Huang, X. (2014). Electrically released iron for fouling control in membrane bioreactors: a double-edged sword? Desalination 347, 10-14. doi: 10.1016/j.desal.2014.05.018

Zhang, K., Wei, P., Yao, M., Field, R. W., and Cui, Z. (2011). Effect of the bubbling regimes on the performance and energy cost of flat sheet MBRs. Desalination 283, 221-226. doi: 10.1016/j.desal.2011.04.023

Zhou, L., Xia, S., and Alvarez-Cohen, L. (2015). Structure and distribution of inorganic components in the cake layer of a membrane bioreactor treating municipal wastewater. Bioresour. Technol. 196, 586-591. doi: 10.1016/j.biortech.2015.08.026

Conflict of Interest Statement: The authors declare that the research was conducted in the absence of any commercial or financial relationships that could be construed as a potential conflict of interest.

Copyright (c) 2016 Ensano, Borea, Naddeo, Belgiorno, de Luna and Ballesteros. This is an open-access article distributed under the terms of the Creative Commons Attribution License (CC BY). The use, distribution or reproduction in other forums is permitted, provided the original author(s) or licensor are credited and that the original publication in this journal is cited, in accordance with accepted academic practice. No use, distribution or reproduction is permitted which does not comply with these terms. 